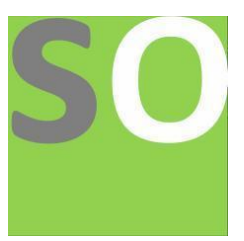

Article title: Isolation and Identification of Fungi Associated with the Spoilage of Sweet Orange and Banana in Sokoto Metropolis

Authors: Michael Ameh[1]

Affiliations: Department of Crop Science, Usman Danfodiyo University, Sokoto[1]

Orcid ids: 0000-0002-2841-7241[1]

Contact e-mail: ameh1314@gmail.com

License information: This work has been published open access under Creative Commons Attribution License http://creativecommons.org/licenses/by/4.0/, which permits unrestricted use, distribution, and reproduction in any medium, provided the original work is properly cited. Conditions, terms of use and publishing policy can be found at https://www.scienceopen.com/.

Preprint statement: This article is a preprint and has not been peer-reviewed, under consideration and submitted to ScienceOpen Preprints for open peer review.

Funder: Self

DOI: 10.14293/S2199-1006.1.SOR-.PPN39LD.v1

Preprint first posted online: 03 November 2020

Keywords: Mycology, Fungi, Pathogenecity, Isolation, Identification, Sweet orange, Banana, Spoilage 


\title{
ISOLATION AND IDENTIFICATION OF FUNGI ASSOCIATED WITH \\ THE SPOILAGE OF SWEET ORANGE (Citrus sinensis L) AND \\ BANANA (Musa sapientum L) IN SOKOTO METROPOLIS
}

\author{
BY
}

AMEH, Michael 


\begin{abstract}
Mycological studies on fungi in apparently diseased sweet orange (Citrus sinensis) and banana (Musa sapientum) sampled from various points in Kara market in Sokoto metropolis was carried out between August and September, 2016. The samples were surfaced sterilized with ethanol and the homogenates were cultured on Potato Dextrose Agar (PDA) and incubated aerobically at room temperature for 7 days at $30^{\circ} \mathrm{C}$. The pure cultures obtained were identified morphologically and microscopically. The investigation revealed that the samples were infected with several fungi species. The most predominant fungi isolated from sweet orange were Cladosporium spp (40\%), Fusarium spp (30\%), Alternaria spp (20\%), and Chrysonilia spp (10\%) while the most predominant fungi isolated from banana were Fusarium spp (50\%), Mucor spp (30\%) and Rhizopus spp (20\%). The pathogenicity test result shows that Cladosporium spp and Fusarium spp were the most active in sweet orange with rot length of $74 \mathrm{~mm}$ and $70 \mathrm{~mm}$ respectively and the least active fungi were Alternaria spp and Chrysonilia spp with rot lengths of $52 \mathrm{~mm}$ and $48 \mathrm{~mm}$ respectively. Furthermore, Fusarium spp and Mucor spp were the most active in banana with rot length of $84 \mathrm{~mm}$ and $75 \mathrm{~mm}$ respectively and the least active fungus was Rhizopus spp with rot length of $54 \mathrm{~mm}$.
\end{abstract}




\section{INTRODUCTION}

Fruit refers to the fleshy seed-associated structures of certain plants that are sweet and eaten in the raw state. They constitute the natural sources of vitamins and mineral nutrients to the body. They are used as nutritional remedies for many patients suffering from different ailments such as diabetes, constipation and stroke (Obeta et al., 2011).

Fruits play a vital role in human nutrition by supplying the necessary growth factors such as vitamins and essential minerals in human daily diet and that can help keep a good and normal health. They are widely distributed in nature and can play an important role in health through the preventer of heart disease and cancer. Fruits and vegetables are different from most fruits that we buy because they are not cooked and they are usually eaten raw. One of the limiting factors that influence the fruit economic value is the relatively short shelf life period caused by pathogens during post-harvest handling even in developed countries (Droby and Zhu, 2006).

Microorganisms are associated, in a variety of ways with all the food we eat. They may influence the quality of our food such as fruits and vegetables which normally contain some microorganisms and maybe contaminated with additional organisms during handling (Lund, 1971). Food can serve as the medium for the growth of microorganisms and as a result transmit diseases. Other microorganisms, if allowed to grow in certain food products, produce toxic substances that result in food poisoning when ingested (Pelczar, 1993). Different disease problem arises when crops are harvested, because seed, fruit or other storage organs are essentially dormant structures and their cells are physiologically unlike those of growing plant (Daveport, 1978). 
Over the years there has been an increasing need to identify and isolate the fungi associated with fruit spoilage. Thus, spoilage refers to any change in the condition of food, in which the food becomes less palatable or even toxic, these changes may be accompanied by alterations in taste, smell, appearance or texture (Paul and Sainsbury, 1981). The occurrence of fungal spoilage of fruits is also recognized as a source of potential health hazard to man and animals. This is due to their production of mycotoxins (naturally occurring toxic chemical often of aromatic structure), compounds which are capable of including mycotoxicoses in man following ingestion and inhalation. They differ in their manner and degree of toxicity (Effiuvwevwere, 2000). 


\section{MATERIALS AND METHODS}

\section{Study Area}

The study area is Sokoto which is the capital city of Sokoto State which lies between latitude $13^{\circ} 349^{\circ} \mathrm{N}$, longitude $5^{\circ} 1489^{\circ} \mathrm{E}$, and at an altitude of $272 \mathrm{~m}$ above the sea level. The occupation of the city inhabitants includes farming, trading, fishing and leather works (Moi, 2008). The Sokoto town is a dry Sudan savannah surrounded by sandy terrain and isolated hills. Rainfall starts by June and ends early September but may sometime extend to October. The average annual rainfall is $550 \mathrm{~m}$ with peak in the month of August. The highest temperature of $45^{\circ} \mathrm{C}$ during the hot season is experienced between the month of November and February (Udo and Mamman, 1993).

\section{Materials and Reagents}

The materials and reagents used in the laboratory for this research work includes; Potato Dextrose Agar (PDA), ethanol, petri dishes, conical flasks, syringes, cotton wool, lactophenol cotton blue, sterilized knife, glass rod, test tubes, streptomycin, nutrient agar, aluminum foil, masking tape, distilled water, face mask, hand gloves, filter paper, microscope, cork borer, slide and cover slip.

\section{Sample Collection}

Two different fruits; sweet orange and banana both fresh and spoilt were purchased from Kara market within the Sokoto metropolis. A total of thirty fruits comprising fifteen fruits from each fruit type were purchased from three different points designated A1 A3 for sweet orange and B1 - B3 for banana and transported to the laboratory in an 
ethanol sterile polythene bag for analysis.

\section{Sterilization of Glasswares}

All the glass wares were first soaked and washed thoroughly with tap water and detergent solution and then rinsed with several changes of distilled water in order to completely remove traces of detergent and air dried completely before sterilizing them in steam oven at temperature of $121^{\circ} \mathrm{C}$ for 15 minutes and then allowed to cool down at room temperature before usage. The entire working surface was also disinfected with ethanol to reduce contamination.

\section{Isolation of Fungi}

Isolation of the fungi was carried out as described by (Amusa et al., 2002). Segment (3$5 \mathrm{~cm}$ ) of tissues from the spoilt fruits was cut with sterile scalpel and placed on potato dextrose agar containing streptomycin (to prevent the growth of bacteria) in petri dishes and incubated at room temperature for 5 days. Pure cultures were obtained from the isolation.

\section{Identification of Fungi}

Identification of the fungi was done according to (Fawole and Oso, 1995). A drop of lactophenol cotton blue stain was placed on a clean slide and with the aid of a mounted needle, a small portion of the mycelium from the fungal cultures was removed and placed in the drop of the stain. The mycelium was spread very well on the slide with the aid of the mounted needles and a cover slip was gently lowered on it. The slide was then examined under the microscope. 
The observation was done at a high power objective $(x 40)$ of the microscope morphological characteristics of the fungi such as type of hyphae and asexual reproductive structure were observed.

\section{Pathogenicity of Isolated Fungi}

Pathogenicity or decay test was carried out in order to know if the isolated fungi were really responsible for the spoilage of citrus and banana fruits. Healthy fruits were surfaced sterilized with ethanol. Cylindrical plug tissues were cut out from the fruits using a sterilized $2 \mathrm{~mm}$ cork borer. Agar plate containing a week old fungal culture were aseptically placed in these holes, then covered and sealed off by means of petroleum jelly. The procedure was repeated separately across each of the fungal isolates. The inoculated samples and the control were placed in sterile polythene bags and incubated in an oven for 5 days. The point of inoculation of each type of fungus was examined and recorded. The diameter of the rotten portion of the orange and banana fruits was measured. The fungi were later re-isolated from the inoculated fruits and compared with the initial isolates.

\section{Data Collected}

The following parameters were recorded;

- Frequency of occurrence of fungal pathogens associated with the spoilt of fruits

- Pathogenicity test result by measuring the diameter of spoilage

Data generated were subjected to analysis by means of descriptive statistics. 


\section{RESULT AND DISCUSSION}

Table 1 shows the quantity of sweet orange and banana fruits bought from the various selling points in Kara market. The table also shows the number of samples infected which is also expressed in percentages. Fifteen fruits were obtained for each of the samples with 5 at each selling point (fruit trader) with each of the samples having a total of 5 healthy fruits and 10 infected fruits i.e. $66.67 \%$ total infected fruits for each sample.

Table 1: Samples of apparently diseased oranges and bananas expressed in percentages

\begin{tabular}{|l|l|l|l|}
\hline SAMPLING POINT & $\begin{array}{l}\text { TOTAL SAMPLES } \\
\text { OBTAINED }\end{array}$ & $\begin{array}{l}\text { TOTAL SAMPLES } \\
\text { INFECTED }\end{array}$ & $\begin{array}{l}\text { PERCENTAGE } \\
\text { SAMPLES } \\
\text { INFECTED }\end{array}$ \\
\hline A1 & 5 & 3 & $60 \%$ \\
\hline A2 & 5 & 2 & $40 \%$ \\
\hline A3 & 5 & 5 & $100 \%$ \\
\hline B1 & 5 & 2 & $40 \%$ \\
\hline B2 & 5 & 4 & $80 \%$ \\
\hline B3 & 5 & 4 & $80 \%$ \\
\hline TOTAL & 30 & 20 & $66.67 \%$ \\
\hline
\end{tabular}


KEY: $A$ = Selling point for sweet orange

$$
B=\text { Selling point for banana }
$$

Table 2 and 3 shows the isolated fungi from the rotten Citrus sinensis and Musa spp fruit and their frequency of occurrence respectively.

Table 2: Frequency of occurrence of various fungal isolates in diseased sweet oranges

\begin{tabular}{lll}
\hline S/N & ORGANISMS IDENTIFIED & FREQUENCY (\%) \\
\hline 1 & Cladosporium spp & $40 \%$ \\
2 & Fusarium spp & $30 \%$ \\
3 & Chrysonilia spp & $10 \%$ \\
4 & Alternaria spp & $20 \%$ \\
\hline
\end{tabular}

Table 3: Frequency of occurrence of various fungal isolates in diseased banana

\begin{tabular}{lll}
\hline $\mathrm{S} / \mathrm{N}$ & ORGANISM IDENTIFIED & FREQUENCY (\%)
\end{tabular}

\begin{tabular}{llc}
\hline 1 & Fusarium spp & $50 \%$ \\
2 & Mucor spp & $30 \%$ \\
3 & Rhizopus spp & $20 \%$ \\
\hline
\end{tabular}


Table 4 and 5 shows the pathogenicity of the isolated fungi from the rotten Citrus sinensis and Musa sapientum fruit after seven days of incubation by measuring the rot length.

Table 4: Decay rate of fungi isolated from Citrus sinensis fruits after 7 days of incubation

FUNGAL ISOLATES $\quad$ LENGTH OF ROT $(\mathrm{mm})$

\section{Cladosporium spp}

Fusarium spp

Chrysonilia spp

Alternaria spp
$74 \mathrm{~mm}$

$70 \mathrm{~mm}$

$48 \mathrm{~mm}$

$52 \mathrm{~mm}$

Table 5: Decay rate of fungi isolated from Musa Sapientum fruits after 7 days of incubation

FUNGAL ISOLATES

LENGTH OF ROT (mm)

Fusarium spp

Mucor spp

Rhizopus spp
$84 \mathrm{~mm}$

$75 \mathrm{~mm}$

$54 \mathrm{~mm}$ 
This study shows that Fusarium spp, Cladosporium spp, Chrysonilia spp and Alternaria spp were found in the spoilt sweet orange while Fusarium spp, Mucor spp and Rhizopus spp were found in the spoilt banana. Out of the fungi isolated from sweet orange, Cladosporium spp and Fusarium spp have the highest frequency of $40 \%$ and $30 \%$, followed by Chrysonilia spp and Alternaria spp $10 \%$ and $20 \%$ frequency of occurrence. Furthermore, out of the fungi isolated from banana, Fusarium spp has the highest frequency of $50 \%$, followed by Mucor spp, $30 \%$ and then Rhizopus spp with $20 \%$, which is the least frequency of occurrence. This is in agreement with (Ifeanyi, 1995) and (Bello, 2010) whom both isolated about seven different genera from different fruits, and when these isolates were aseptically inoculated into healthy susceptible fruits, the characteristic symptoms originally observed were also noticed. All the organisms were successfully taking part in the decay and are thus confirmed as the usual causal organism of fruit decay (Baiyewu et al., 2007; Chukwuka et al., 2010). Thus, these fungi were also found to be associated with the deterioration of sweet orange and banana fruits. All the organisms isolated were confirmed to cause spoilage on the sweet orange and banana fruits but in varying degrees. Of all the isolated fungi from sweet orange, Cladosporium spp and Fusarium spp were the most pathogenic (virulent) with rapid disintegration of the fruits in 7 days having a rot length of $74 \mathrm{~mm}$ and $70 \mathrm{~mm}$ respectively while the least pathogenic fungi were Alternaria spp and Chrysonilia spp having rot lengths of $52 \mathrm{~mm}$ and $48 \mathrm{~mm}$ respectively. The most pathogenic fungi for the banana fruit was Fusarium spp and Mucor spp having a rot length of $84 \mathrm{~mm}$ and $75 \mathrm{~mm}$ respectively while the least pathogenic fungus was Rhizopus spp with rot length of 54 $\mathrm{mm}$. 
Some fungi may produce mycotoxins (Toumas and Stack, 2001). The fungi isolated in this study have been reported to produce secondary metabolites in plant tissues. These secondary metabolites are potentially harmful to humans and animals (Eaton and Groopman, 1994; Baiyewu et al., 2007). A good example is aflatoxin which has been implicated in cancer of the liver (heplatoma), aflatoxicosis and also acute hepatitis in humans, especially in the developing world (Krogh, 1992; Prasad, 1992; Eaton and Groopman, 1994; Muhammad et al., 2004; Baiyewu et al., 2007). Pathogenic fungi, on the other hand, could also cause infections or allergies (Monso, 2004). 


\section{CONCLUSION}

In this study, Cladosporium spp, Fusarium spp, Chrysonilia spp and Alternaria spp were detected in spoilt sweet orange, while Fusarium spp, Mucor spp and Rhizopus spp were found in banana. The presence of these fungi on sweet orange and banana fruits poses a serious threat to the health of consumers as the organism could produce mycotoxins, which are harmful when consumed. Most of the fungi isolated were observed to be able to infect healthy orange and banana fruits within a short time, which poses a serious economic threat to sellers of these fruits in Sokoto metropolis. 


\section{REFERENCES}

Amusa, N. A., Kehinde, I. A., and Ashaye, O. A. (2002). Bio-deterioration of Breadfruit (Artocrarpus communis) in Storage and its Effects on the Nutrient Composition. African Journal of Biotechnology, 1(2), 57-60.

Baiyewu, R.A., Amusa, N.A., Ayoola, O.A. and Babalola, O.O. (2007). Survey of the Postharvest Diseases and Aflatoxin Contamination of Marketed Pawpaw (Carica papaya) L.) Fruit Decay in Oyo State, Nigeria. American-Eurasian Journal of Toxicological Sciences, 2(1): 43-50

Chukwuka, K.S., Okonko, I.O and Adekunle, A.A. (2010). Microbial Ecology of Organisms

Causing Pawpaw (Carica Papaya L.) Fruit Decay in Oyo State, Nigeria. AmericanEurasian Journal of Toxicological Sciences, 2(1): 43-50

Daveport, M. (1978): Fruit Spoilage by Some Selected Molds. Phytology. Rev. 13:8

Droby, S. (2006). Improving Quality and Safety of Fresh Fruits and Vegetables after Harvest by the Use of Biocontrol Agents and Natural Materials. Acta Horticulturae. 709: 45-51

Eaton, D.L and Groopman, J.D. (1994). Thetoxicology of Aflatoxins, Academic Press, New York, NY; Pp. 383-424.

Effiuvwevwere, B.J.O. (2000). Microbial Spoilage Agents of Tropical and Assorted Fruits and Vegetables, Paragraphics Publishing Company, Port Harcourt; pp, 1-39.

Fawole, M.O. and Oso, B.A. (1995): Laboratory Manual of Microbiology. 1st Edition. Spectrum Books Ltd, Ibadan, Nigeria Pp. 34-35. 
Ifeanyi, A.E. (1995). Fungi Associated with the Deterioration of Citrus sinensis. B.sc. Biology, Usmanu Danfodiyo University Sokoto, Nigeria (Unpublished)

Krogh, P. (1992). Adverse Effect of Mycotoxins on Human Health in Seed Pathology. In Mathur, S.B and Jorgensen, J. (Eds), Proceedings of the Seminar, 20-25, June 1988, Copenhagen, Denmark, Pp. 149-157.

Lund, D.M. (1971). Bacterial Spoilage of Vegetable and Certain Fruits, Journal of Applied Bacteriology, 34:9-20

MOI (2008). Ministry of Information, Sokoto, Nigeria. Diary, Pp, 12.

Monso, E.M. (2004). Occupational Asthma in Greenhouse Workers, Current Opinion in Pulmonary Medicine, 10: 147-150.

Muhammad, S., Shehu, K. and Amusa, N.A. (2004). Survey of the Market Diseases and Aflatoxin Contamination of Tomato (Lycopersicon esculentum MILL) Fruits in Sokoto North Western Nigeria, Journal of Nutrition and Food Science, 34: Pp. 72-76.

Obeta, S.E., Nwakonobi, T.U., and Adikwu, O.A. (2011). Microbial Effect of Selected Stored Fruits and Vegetables under Ambient Conditions in Makurdi, Benue State, Nigeria. Research Journal of Applied Science and Engineering Technology, 3(5). 393-398

Paul, S., and Sainsbury, D. (1981). Dictionary of Microbiology, John Wiley and Son's Publication, New York.

Pelczar, M.J. (1993): Microbiology. 5th Edition. Mac Graw Hill Publishing Company. Pp. 113-115. 
Prasad, T. (1992). Plant Pathogenesis and Disease Control. Plant Disease Journal of Japan Acado, 56: 367.

Tournas, V.H. and Stack, M.E. (2001). Production of Alternariol and Alternariol Methyl Ether by Alternaria Alternata Grown on Fruits at Various Temperatures. Journal of Food Protection, 64: 528-532

Udo, R.K., and Mamman, A.B. (1993). Giant in the Tropics, State Surveys, Pp 435-446.

Zhu, S.J (2006). Non-chemical Approaches to Decay Control in Postharvest Fruit. In: Noureddine B, Norio S. (Eds.), Advances in Postharvest Technologies for Horticultural Crops. Research Signpost, Trivandrum, India; Pp 297-313 